\title{
Role of protease-activated receptor-2 on cell death and DNA fragmentation in Helicobacter pylori-infected gastric epithelial cells
}

\author{
Joo Weon Lim, Hyeyoung Kim
}

\begin{abstract}
Background: Helicobacter pylori (H. pylori) infection is associated with chronic gastritis, peptic ulceration and gastric carcinoma. Protease-activated receptor-2 (PAR-2), which is activated by trypsin, induced the activation of mitogenactivated protein kinases (MAPK), cell proliferation and apoptosis in several cells. Previously, we found that H. pylori induces the expression of PAR-2, which mediates the expression of adhesion molecules integrins in gastric epithelial cells. In the present study, the role of PAR-2 on H. pylori-induced cell death was investigated by determining cell viability, DNA fragmentation, and the activation of MAPK in gastric epithelial AGS cells.

Methods: AGS cells were cultured in the presence of H. pylori transfected with PAR-2 antisense (AS) oligonucleotide (ODN) or treated with a soybean trypsin inhibitor (SBTI). Viable cells and DNA fragmentation were determined by trypan blue exclusion assay and the amount of oligonucleosome-bound DNA, respectively. The activation of MAPK such as extracellular signal-regulated kinases (ERK), p38, and c-Jun N-terminal kinases (JNK), was assessed by Western blotting for phospho-specific forms of MAPK.
\end{abstract}

Results: H. pylori-induced cell death and DNA fragmentation augmented in the cells transfected with PAR-2 AS ODN or treated with SBTI. The activation of MAPK, induced by H. pylori, were suppressed by transfection with PAR2 AS ODN or treatment with SBTI.

Conclusion: PAR-2, whose expression is induced by H. pylori, may prevent cell death and DNA fragmentation with the activation of MAPK in gastric epithelial cells.

\section{Background}

Helicobacter pylori (H. pylori) has been shown to be an important pathogen of gastroduodenal inflammation and gastric carcinogenesis [1,2]. H. pylori infection increases epithelial apoptosis in gastric mucosa, which may play an important role in gastric carcinogenesis [3]. H. pylori-induced apoptosis may stimulate compensatory hyperproliferation which results in potential preneoplastic changes in chronic H. pylori infection [4-6]. H. pylori -induced apoptosis has been shown in gastric epithelial cells $[7,8]$ as well as infected gastric tissues $[6,9,10]$. However, the apoptotic mechanism induced by $H$. pylori infection has not been fully elucidated.

\footnotetext{
* Correspondence: kim626@yonsei.ac.kr

Department of Food and Nutrition, Brain Korea 21 Project, College of Human Ecology, Yonsei University, Seoul 120-749, Korea
}

H. pylori activates three main groups of mitogen-activated protein kinases (MAPKs), i.e., the extracellular signal-regulated kinases 1 and 2 (ERK1/2), p38 MAPKs, and c-Jun N-terminal kinases [11,12]. Recently, it was shown that inhibition of the ERK1/2 pathway augmented $H$. pylori-induced apoptosis in gastric epithelial cells [13], demonstrating the possible involvement of MAPK in gastric apoptosis.

Proteinase-activated receptors (PARs), a family of G protein-coupled seven-trans-membrane domain receptors, mediate a variety of intracellular signaling and subsequent cellular events caused by specific extracellular proteinases $[14,15]$. The family of PARs currently includes four members: PAR-1, PAR-2, PAR-3 and PAR4. The coagulant protease thrombin is the physiological activator of PAR-1, PAR-3, and PAR-4. PAR-2 is activated by multiple trypsin-like serine proteases including trypsin, tryptase and coagulation protease 
upstream of thrombin. Activation of PAR-2 triggers the activation of multiple signaling pathways, including MAPK cascades in distinct cell types $[16,17]$. PAR-2 is involved in cell proliferation and apoptosis in several cell types $[18,19]$. Recent data suggest that activation of PAR-2 rescued cells from apoptosis via activation of MAPKs [20]. We previously demonstrated that $H$. pylori induces the activation and expression of PAR-2 in gastric epithelial cells $[21,22]$. These results demonstrate the possible relations of the expression of PAR-2, the activation of MAPK, and apoptosis in $H$. pylori-infected gastric epithelial cells. The present study aims to investigate whether $H$. pylori-induced apoptotic cell death is related to the expression of PAR-2 and the activation of MAPK in gastric epithelial cells.

\section{Methods}

\section{Bacterial strain}

An H. pylori strain used in the present study is HP99 isolated form Korean patients and identified as cagA+, vacA+ strain [12]. HP99 is kindly provided from Dr. H. C. Jung (Seoul National University College of Medicine, Seoul, Korea). These bacteria were inoculated onto chocolate agar plates (Becton Dickinson Microbiology Systems, Cockeysville, MD, USA) at $37^{\circ} \mathrm{C}$ under microaerophilic conditions using an anaerobic chamber (BBL Campy Pouchs System, Becton Dickinson Microbiology Systems).

\section{Cell culture and $H$. pylori stimulation}

A human gastric epithelial cell line AGS (gastric adenocarcinoma, ATCC CRL 1739) was obtained from the American Type Culture Collection (Rockville, MD, USA). The cells were grown in complete medium, consisting of RPMI 1640 medium supplemented with 10\% fetal bovine serum, $2 \mathrm{mM}$ glutamine, $100 \mathrm{U} / \mathrm{ml}$ penicillin, and $100 \mu \mathrm{g} / \mathrm{ml}$ streptomycin (Sigma, St. Louis, MO, USA). AGS cells were seeded and cultured to reach $80 \%$ confluency. Prior to the stimulation, each dish was washed twice with fresh cell culture medium containing no antibiotics. H. pylori was harvested, washed with phosphate buffered saline (PBS), and then resuspended into antibiotic-free cell culture medium. H. pylori was added to AGS cells at bacterium/cell ratio of 150:1 or $300: 1$, and cultured for the indicated time periods.

\section{Experimental protocol}

To investigate the relations of apoptotic cell death, the expression of PAR-2, and the activation of MAPK in $H$. pylori-infected gastric epithelial cells, cell viability and DNA fragmentation were determined in the cells transfected with PAR-2 AS ODN or S ODN or treated with soybean trypsin inhibitor (SBTI; $0.2 \mu \mathrm{M}, 0.5 \mu \mathrm{M}$ ) and cultured in the presence of $H$. pylori at bacterium/cell ratio of 150:1 (cell viability) or 300:1 (cell viability, DNA fragmentation) for 24 hours. For the activation of MAPK, AGS cells were transfected with PAR-2 AS ODN or S ODN or treated with soybean trypsin inhibitor (SBTI; $0.2 \mu \mathrm{M}, 0.5 \mu \mathrm{M}$ ) and cultured in the presence of $\mathrm{H}$. pylori at bacterium/cell ratio of 300:1 for $30 \mathrm{~min}$ utes. To determine the transfection efficiency of PAR-2 AS ODN or S ODN, the level of PAR-2 was determined in the transfected cells cultured in the presence of H. pylori at bacterium/cell ratio of 300:1 for 2 hours.

\section{Determination of cell viability and DNA fragmentation}

AGS cells were cultured in the presence of $H$. pylori at a bacterium/cell ratio of $150: 1$ or $300: 1$ for 24 hours. Viable cells were determined by trypan blue exclusion test (0.2\% trypan blue). DNA fragmentation was determined by the amount of oligonucleosome-bound DNA in the cell lysates using a sandwich ELISA (Cell Death Detection ELISAplus kit; Boehringer-Mannheim). The relative increase in oligonucleosome-bound DNA was determined at $405 \mathrm{~nm}$ and expressed as an enrichment factor.

\section{Treatment with ODNs using cationic liposome}

Single-stranded oligonuceltides (ODNs) were produced commercially (GIBCO BRL, Rockville, MD, USA). ODNs were phosphorothioate-modified to reduce intracellular nuclease digestion. Antisense (AS) and sense (S) ODNs targeted the ATG start codon of the human PAR-2 mRNA [GenBank: AY336105.1]. The sequence of the PAR-2 AS ODN was 5'TCCGCATCCTCCTGGAA3'. The sequence of PAR-2 S ODN was 5'TTCCAGGAGGATGCGGA3'. AGS cells were transfected with ODNs using a cationic liposome, a commercially available transfection-reagent DOTAP (N-[1-(2,3-dioleoyloxy) propyl]N, N, Ntrimethyl ammonium methylsulfate) (BoehringerMannheim, Pentzberg, Germany) to improve stability and intracellular delivery of ODNs. When DOTAP was employed, the appropriate amount of ODNs were incubated with DOTAP $(15 \mu \mathrm{l} / \mathrm{ml})$ to achieve the respective final concentration of the ODNs to $0.5 \mu \mathrm{M}$ at $37^{\circ} \mathrm{C}$ for $15 \mathrm{~min}$. The cells were treated with the mixture and then incubated for 24 hours. After medium was changed with antibiotic-free medium, the transfected cells were cultured in the presence of $H$. pylori.

\section{Western blot analysis}

One hundred $\mu \mathrm{g}$ of whole cell extracts was loaded per lane, separated by SDS-polyacrylamide gel electrophoresis (PAGE) under reducing conditions, and transferred onto Hybond-PVDF membranes (Amersham Inc., Arlington Heights, IL, USA) by electroblotting. The transfer of protein and equality of loading in all lanes was verified using reversible staining with Ponceau S. 
Membranes were blocked using 5\% nonfat dry milk. PAR-2, ERK1/2, p38, and JNK1/2 were detected by incubation of blots with specific polyclonal antibodies, followed by sheep anti-mouse secondary antibody conjugated to horseradish peroxidase. The proteins were determined by enhanced chemiluminescence (Amersham) using exposure to BioMax MR film (Kodak).

\section{Statistical analysis}

Results are expressed as means \pm standard error of four separate experiments. Analysis of variance (ANOVA) followed by Newman-Keul's test was used for statistical analysis. $P<0.05$ was considered statistically significant

\section{Results}

Inhibition of PAR-2 expression augments $H$. pyloriinduced cell death and DNA fragmentation in gastric epithelial cells

To investigate the relations of PAR-2 expression, cell death, and DNA fragmentation, cells were transfected with AS ODN for PAR-2 and cultured in the presence of $H$. pylori. As shown in figure 1, H. pylori induced the expression of PAR-2, which was inhibited in the cells transfected with PAR-2 AS ODN. Viable cell numbers were decreased by $H$. pylori with the number of bacterium infected to the cells (Figure 2A). Cell death of H. pylori-infected cells was augmented by transfection

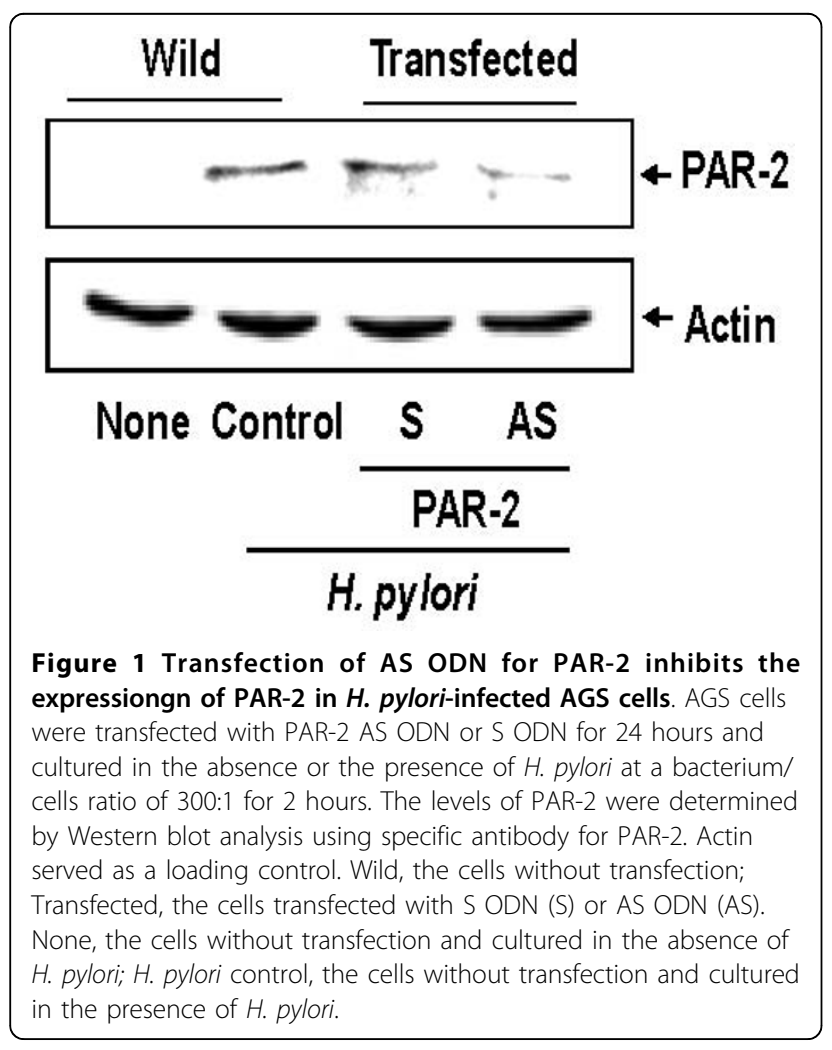

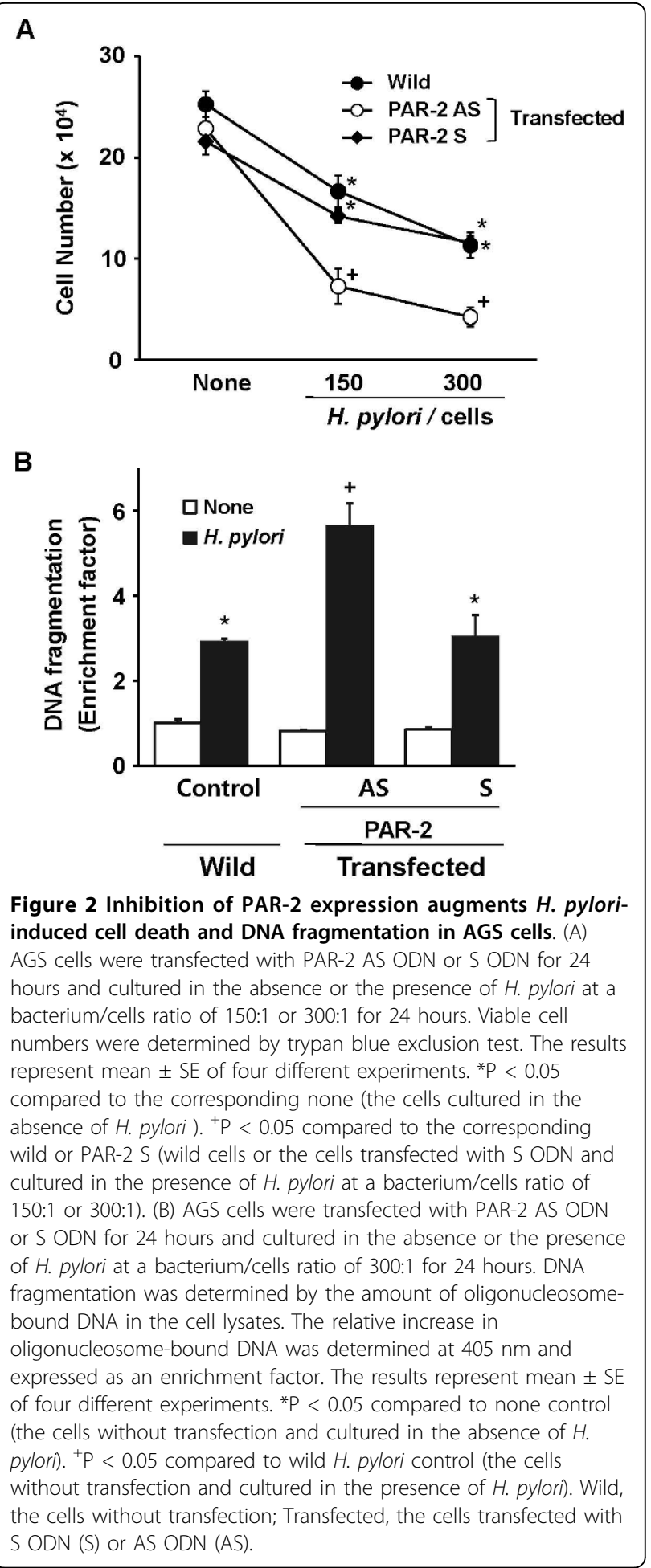

with PAR-2 AS ODN, compared with that of the cells transfected with S ODN or wild cells (non-transfected cells). Similarly, $H$. pylori-induced DNA fragmentations increased by transfection with PAR-2 AS ODN, compared with corresponding S ODN or wild cells (Figure 
2B). These results suggest that $H$. pylori- induced expression of PAR-2 may have a protective role against apoptosis of gastric epithelial cells, determined by cell death and DNA fragmentation.

Inhibition of PAR-2 expression suppresses $H$. pyloriinduced activation of MAPK in gastric epithelial cells

To determine the role of PAR-2 on the activation of MAPK, the activation of three major MAPK involved in cell proliferation and apoptosis were assessed by Western blotting of phospho-specific and total forms of MAPK (p38, ERK1/2, JNK1/2). As shown figure 3, levels of phospho-specific forms of p38, ERK1/2, and JNK1/2 increased by $H$. pylori in AGS cells. $H$. pylori did not affect total forms of p38, ERK1/2, and JNK1/2 in AGS cells. H. pylori-induced activation of MAPK was inhibited in the cells transfected with PAR-2 AS ODN, but that was not affected in the cells transfected with $S$ ODN. These results demonstrate that both $H$. pyloriinduced expression of PAR-2 and activation of MAPK may be related to cell viability of gastric epithelial cells after $H$. pylori infection.

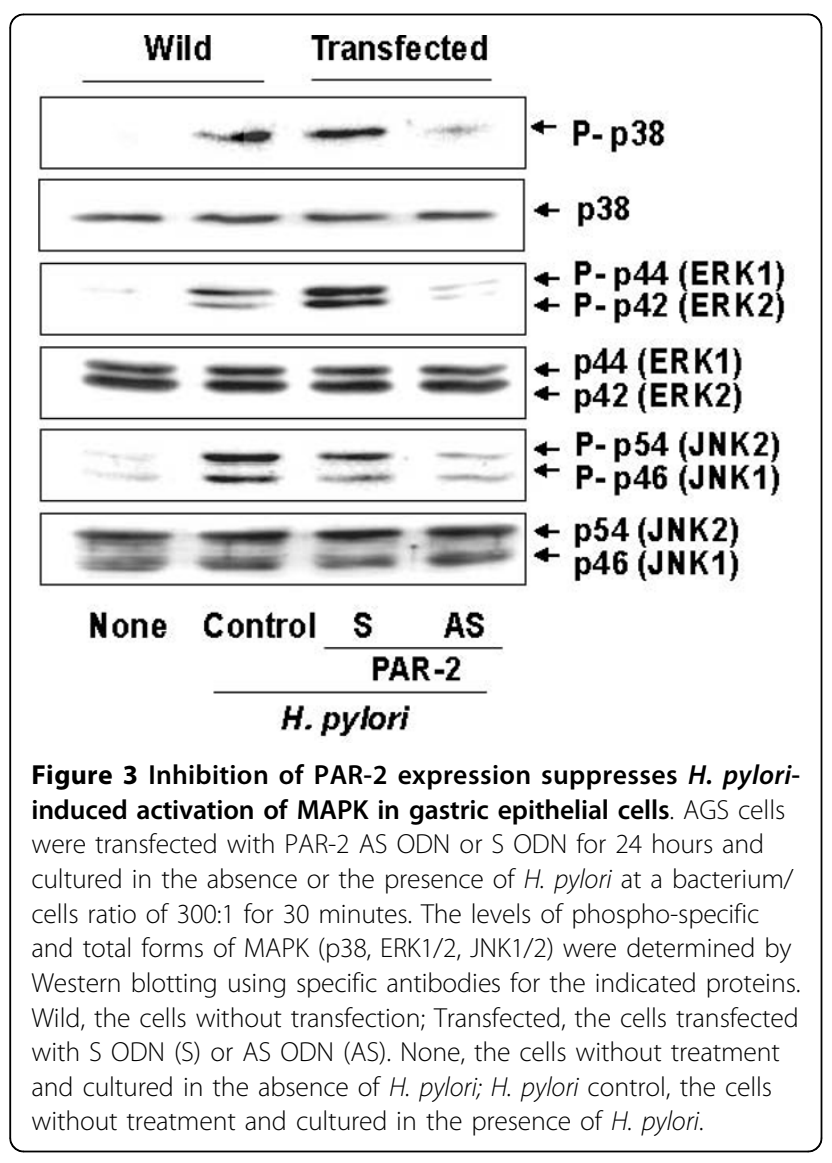

Soybean trypsin inhibitor (SBTI) augments $H$. pyloriinduced cell death and DNA fragmentation in gastric epithelial cells concentration-dependently

Since PAR-2 is activated by trypsin $[14,15]$, SBTI was treated to the cells and cultured in the presence of $H$. pylori to suppress the activity of PAR-2. Viable cell numbers were decreased by $H$. pylori with the number of bacterium infected to the cells (Figure 4A). Cell death of $H$. pylori-infected cells was augmented by treatment of SBTI concentration-dependently. $H$. pylori-induced DNA fragmentations increased by treatment of $0.5 \mu \mathrm{M}$ of SBTI (Figure 4B). These results suggest that inhibition of trypsin activity, which induces the suppression of PAR-2 activity, augments $H$. pylori-induced cell death and DNA fragmentation.

Soybean trypsin inhibitor (SBTI) suppresses $H$. pyloriinduced activation of MAPK in gastric epithelial cells

$H$. pylori -induced increases in phospho-specific forms of $\mathrm{p} 38, \mathrm{ERK} 1 / 2$, and JNK1/2 were inhibited by treatment by treatment of SBTI in AGS cells concentration-dependently (figure 5 ). As shown figure $3, H$. pylori did not affect total forms of p38, ERK1/2, and JNK1/2 in AGS cells, which was not affected by treatment of SBTI (figure 5). These results suggest that PAR2, which may be activated by trypsin, may be involved in the activation of MAPK in $H$. pylori-infected gastric epithelial cells.

\section{Discussion}

In the present study, we found that $H$. pylori-induced cell death and DNA fragmentation were augmented by inhibition of PAR-2 expression using PAR-2 AS ODN in AGS cells. Additionally, inhibition of PAR-2 activity using trypsin inhibitor increased cell death and DNA fragmentation in $H$. pylori-infected AGS cells. These results demonstrate that the expression and the activation of PAR-2 induced by $H$. pylori may prevent apoptotic cell death in gastric epithelial cells.

Previously we demonstrated that $H$. pylori induced the expression and activation of PAR-2, which mediates the expression of COX-2 and integrins in gastric epithelial cells [21,22]. Trypsin activated PAR-2, which mediated the proliferation of various cells including pancreatic and gastric cancer cells, and smooth muscle cells [23-25]. Additionally, activation of PAR-2 by agonist or activating peptide protects astrocytes and neutrophils against apoptotic cell death [26,27]. These studies support the present results showing that $H$. pylori-induced expression of PAR-2 may protect gastric epithelial cells from cell death and DNA fragmentation.

Furthermore, we here found that activation of MAPK was mediated by PAR-2 in $H$. pylori-infected gastric 

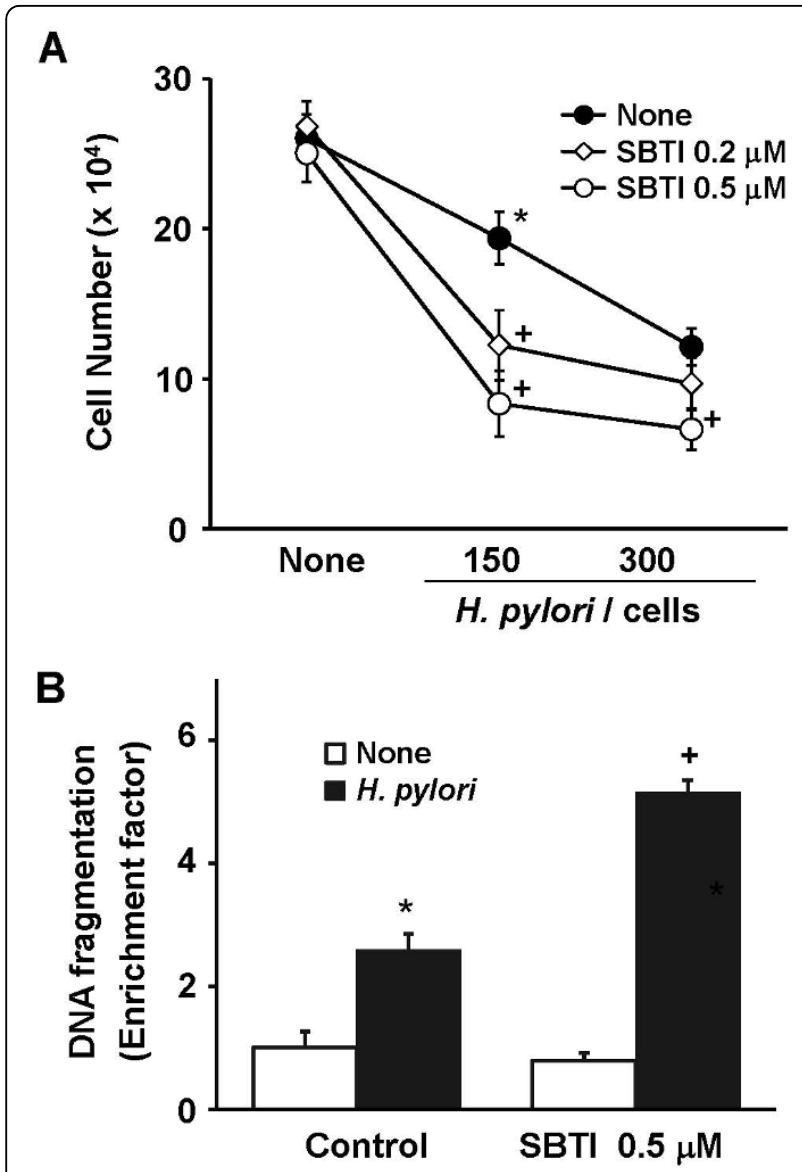

Figure 4 Soybean trypsin inhibitor (SBTI) augments $H$. pyloriinduced cell death and DNA fragmentation in gastric epithelial cells concentration-dependently. (A) AGS cells were treated with SBTI $(0.2 \mu \mathrm{M}, 0.5 \mu \mathrm{M})$ and cultured in the absence or the presence of $\mathrm{H}$. pylori at a bacterium/cells ratio of 150: or 300:1 for 24 hours. Viable cell numbers were determined by trypan blue exclusion test. The results represent mean \pm SE of four different experiments. ${ }^{*} P<$ 0.05 compared to none (the cells without treatment and cultured in the absence of $\mathrm{H}$. pylori). ${ }^{+} \mathrm{P}<0.05$ compared to the corresponding none (the cells without treatment and cultured in the presence of H. pylori at a bacterium/cells ratio of 150: or 300:1). (B) AGS cells were treated with SBTI $(0.5 \mu \mathrm{M})$ and cultured in the absence or the presence of $\mathrm{H}$. pylori at a bacterium/cells ratio of 300:1 for 24 hours. DNA fragmentation was determined by the amount of oligonucleosome-bound DNA in the cell lysates. The relative increase in oligonucleosome-bound DNA was determined at 405 $\mathrm{nm}$ and expressed as an enrichment factor. The results represent mean \pm SE of four different experiments. ${ }^{*} P<0.05$ compared to none control (the cells without treatment and cultured in the absence of $\mathrm{H}$. pylori). ${ }^{+} \mathrm{P}<0.05$ compared to $\mathrm{H}$. pylori control (the cells without treatment and cultured in the presence of $H$. pylori).

epithelial cells. This result is consistent with the previous studies showing that the activation of PAR-2 is related to the activation of MAPK in mouse tracheal and bronchial smooth muscle [16,17]. The MAPK signaling pathways play essential roles in cell proliferation and apoptosis $[18,19]$. MAPK activated by $H$. pylori

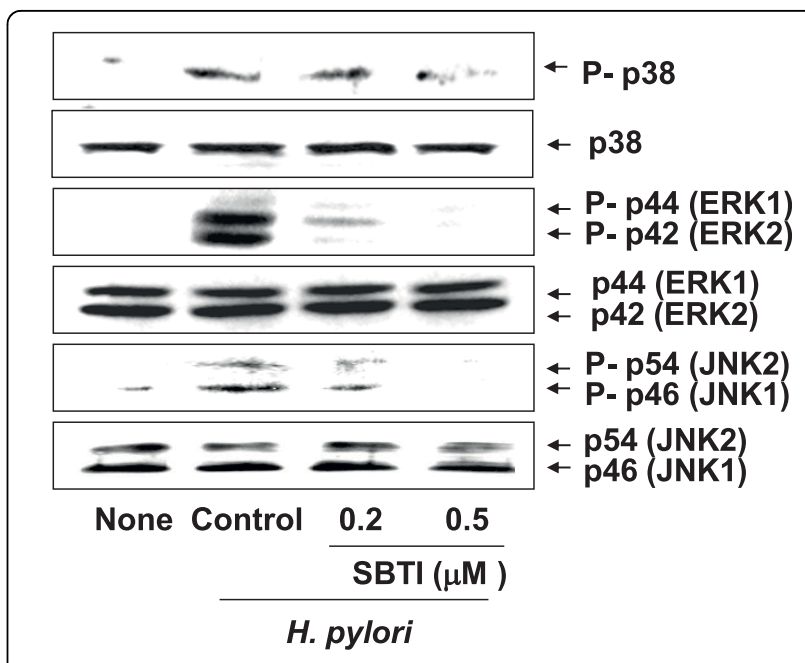

Figure 5 Soybean trypsin inhibitor (SBTI) suppresses $H$. pyloriinduced activation of MAPK in gastric epithelial cells. AGS cells were treated with SBTI and cultured in the absence or the presence of $\mathrm{H}$. pylori at a bacterium/cells ratio of 300:1 for 30 minutes. The levels of phospho-specific and total forms of MAPK (p38, ERK1/2, JNK1/2) were determined by Western blotting using specific antibodies for the indicated proteins. None, the cells without treatment and cultured in the absence of H. pylori; H. pylori control, the cells without treatment and cultured in the presence of $\mathrm{H}$. pylori.

infection is involved in apoptosis of gastric epithelial cells [28-30]. Ding et al. [28] demonstrated that inhibition on the activation of ERK $1 / 2$, JNK $1 / 2$ or p 38 by treatment of the chemical inhibitor increased $H$. pyloriinduced apoptosis in gastric epithelial cells. These studies suggest that PAR-2 activation induced by $H$. pylori may protect gastric epithelial cells from apoptosis by the activation of MAPK. In contrast, inhibition of p38 by a specific inhibitor SB203580 decreased apoptosis while ERK1/2 inhibition by a specific inhibitor PD 98059 resulted in an increase of apoptosis in $H$. pylori-infected gastric epithelial cells [29]. Further studies should be performed to investigate the role of PAR-2 on the activation of specific MAPK and its relation to the expression of apoptotic genes in $H$. pylori-infected gastric epithelial cells. Recently it was reported that other PARs such as PAR-1 and PAR-4 protect cell apoptosis through ERK or JNK signaling pathway [30-34]. Therefore, the expression and activation of PAR-2 induced by H. pylori may rescue gastric epithelial cells from apoptosis via MAPK signaling.

Other possible protective proteins other than PARs, antiapoptotic proteins such as inhibitors-of-apoptosisproteins (IAPs) were induced by NF- $\kappa \mathrm{B}$ activation and protected the cells from apoptosis induced by the wildtype $H$. pylori containing virulence factor cytotoxinassociated gene (cagA) [35]. Molecular chaperone heat shock protein 70 protected gastric injury against 
monochloramine which is generated by neutrophilderived hypochlorous acid and $H$ pylori urease-induced ammonia [36]. H. pylori infection upregulated gastric mucosal peroxiredoxin (Prx) I expression, and further, that Prx I played an important role in gastric mucosal protection against oxidative injury induced by $H$. pylori infection [37]. Recently, it was found that the disturbances in gastric mucosal $\mathrm{NO}$ generation system caused by $H$. pylori resulted from the inducible nitric oxide synthase (iNOS). They demonstrated that peptide hormone ghrelin protected gastric mucosa from $H$. pyloriinduced proapoptotic events by a decrease in S-nitrosylation of constitutive nitric oxide synthase (cNOS) [38].

Regarding virulence factors of $H$. pylori, cagA and vacuolating cytotoxin $\mathrm{A}(\mathrm{vac} A)$ are reported to contribute to gastric cancer incidence [39,40]. Since $H$. pylori in Korean isolates, HP99 used in the present study, contains both cagA and $v a c A$ [41], the present result may explain the possible mechanism of $H$. pylori-induced gastric carcinogenesis. Further study should be performed to investigate the mechanism of gastric carcinogenesis involving PAR-2-associated prevention against apoptosis of gastric epithelial cells infected with $H$. pylori containing different isotypes of virulence factors.

\section{Conclusion}

PAR-2, whose expression is induced by $H$. pylori, may prevent cell death and DNA fragmentation with the activation of MAPK in gastric epithelial cells. These results demonstrate a novel mechanism of protection against apoptotic cell death by PAR-2 in $H$. pyloriinfected gastric epithelial cells.

\section{Abbreviations}

AS: antisense; MAPK: mitogen-activated protein kinase; ODN: oligonucleotide; PAR: protease-activated receptor; S: sense; SBTI: soybean trypsin inhibitor

\section{Acknowledgements}

This work was supported by a Korea Research Foundation Grant funded by the Korean Government (MOEHRD) (KRF-2006-353-E00008) (to J. W. Lim) and Basic Science Research Program through the National Research Foundation of Korea (NRF) funded by the Ministry of Education, Science and Technology (2010-0001669, 2010-0002916) (to H. Kim). H. Kim is grateful to the Brain Korea 21 Project, Yonsei University.

\section{Authors' contributions}

All authors read and approved the final manuscript.

\section{Competing interests}

The authors report no conflicts of interest. The authors alone are responsible for the content and writing of the paper.

Received: 15 January 2010 Accepted: 16 September 2010 Published: 16 September 2010

\section{References}

1. Negrini R, Savio A, Poiesi C, Appelmelk BJ, Buffoli F, Paterlini A, Cesari P, Graffeo M, Vaira D, Franzin G: Antigenic mimicry between Helicobacter pylori and gastric mucosa in the pathogenesis of body atrophic gastritis. Gastroenterology 1996, 111:655-665.

2. Parsonnet J, Friedman GD, Vandersteen DP: Helicobacter pylori infection and the risk of gastric carcinoma. N Eng/ J Med 1991, 325:1127-1131.

3. Xia HH, Talley NJ: Apoptosis in gastric epithelium induced by Helicobacter pylori infection: implications in gastric carcinogenesis. Am J Gastroenterol 2001, 96:16-26.

4. Hall PA, Coates PJ, Ansari B, Hopwood D: Regulation of cell number in the mammalian gastrointestinal tract: the importance of apoptosis. J Cell Sci 1994, 107:3569-3577.

5. Jones NL, Shannon PT, Cutz E, Yeger H, Sherman PM: Increase in proliferation and apoptosis of gastric epithelial cells early in the natural history of Helicobacter pylori infection. Am J Pathol 1997, 151:1695-1703.

6. Moss SF, Calam J, Agarwal B, Wang S, Holt PR: Induction of gastric epithelial apoptosis by Helicobacter pylori. Gut 1996, 738:498-501.

7. Peek RM Jr, Blaser MJ, Mays DJ, Forsyth MH, Cover TL, Song SY, Krishna U, Pietenpol JA: Helicobacter pylori strain-specific genotypes and modulation of the gastric epithelial cell cycle. Cancer Res 1999, 59:6124-6131.

8. Rudi J, Kuck D, Strand S, von Herbay A, Mariani SM, Krammer PH, Galle PR, Stremmel W: Involvement of the CD95 (APO-1/Fas) receptor and ligand system in Helicobacter pylori-induced gastric epithelial apoptosis. J Clin Investig 1998, 102:1506-1514.

9. Konturek PC, Pierzchalski P, Konturek SJ, Meixner H, Faller G, Kirchner T, Hahn EG: Helicobacter pylori induces apoptosis in gastric mucosa through an upregulation of Bax expression in humans. Scand J Gastroenterol 1999, 34:375-383.

10. Bhattacharyya A, Chattopadhyay R, Burnette BR, Cross JV, Mitra S, Ernst PB, Bhakat KK, Crowe SE: Acetylation of apurinic/apyrimidinic endonuclease-1 regulates Helicobacter pylori-mediated gastric epithelial cell apoptosis. Gastroenterology 2009, 136:2258-2269.

11. Kim H: Oxidative stress in Helicobacter pylori-induced gastric cell injury. Inflammopharmacology. Inflammopharmacology 2005, 13:63-74.

12. Seo JH, Lim JW, Kim H, Kim KH: Helicobacter pylori in a Korean isolate activates mitogen-activated protein kinases, AP-1, and NF-kB and induces chemokine expression in gastric epithelial AGS cells. Lab Invest 2004, 84:49-62.

13. Choi IJ, Kim JS, Kim JM, Jung HC, Song IS: Effect of inhibition of extracellular signal-regulated kinase 1 and 2 pathway on apoptosis and bcl-2 expression in Helicobacter pylori-infected AGS cells. Infect Immun 2003, 71:830-837.

14. Hollenberg MD, Compton SJ: International Union of Pharmacology. XXVIII. Proteinase-activated receptors. Pharmacol Rev 2002, 54:203-217.

15. Ossovskaya VS, Bunnett NM: Protease-activated receptors: contribution to physiology and disease. Physiol Rev 2004, 84:579-621.

16. Coelho AM, Ossovskaya V, Bunnett NW: Proteinase-activated receptor-2: physiological and pathophysiological roles. Curr Med Chem Cardiovasc Hematol Agents 2003, 1:61-72.

17. Kawabata A, Kubo S, Ishiki T, Kawao N, Sekiguchi F, Kuroda R, Hollenberg MD, Kanke T, Saito N: Proteinase-activated receptor-2mediated relaxation in mouse tracheal and bronchial smooth muscle: signal transduction mechanisms and distinct agonist sensitivity. J Pharmacol Exp Ther 2004, 311:402-410.

18. Chinni C, de Niese MR, Jenkins AL, Pike RN, Bottomley SP, Mackie EJ: Protease-activated receptor-2 mediates proliferative responses in skeletal myoblasts. J Cell Sci 2000, 113(Pt 24):4427-4433.

19. Shpacovitch VM, Seeliger S, Huber-Lang M, Balkow S, Feld M, Hollenberg MD, Sarma VJ, Ward PA, Strey A, Gerke V, Sommerhoff CP, Vergnolle N, Steinhoff M: Agonists of proteinase-activated receptor-2 affect transendothelial migration and apoptosis of human neutrophils. Exp Dermatol 2007, 16:799-806.

20. Wang $Y$, Luo $W$, Reiser G: Proteinase-activated receptor-1 and -2 induce the release of chemokine GRO/CINC-1 from rat astrocytes via differential activation of JNK isoforms, evoking multiple protective pathways in brain. Biochem J 2007, 401:65-78.

21. Seo JH, Kim KH, Kim H: Role of proteinase-activated receptor-2 on cyclooxygenase-2 expression in H. pylori-infected gastric epithelial cells. Ann NY Acad Sci 2007, 1096:29-36.

22. Seo JH, Lim JW, Yoon JH, Kim KH: Proteinase-activated receptor-2 mediates the expression of integrin alpha5 and beta1 in Helicobacter pylori-infected gastric epithelial AGS cells. Digestion 2009, 80(1):40-9. 
23. Yoshida N, Yoshikawa T: Basic and translational research on proteinaseactivated receptors: implication of proteinase/proteinase-activated receptor in gastrointestinal inflammation. J Pharmacol Sci 2008, 108:415-21.

24. Hirano J, Kanaide $\mathrm{H}$ : Role of protease-activated receptors in the vascular system. J Atheroscler Thromb 2003, 10:211-225.

25. Caruso R, Pallone F, Fina D, Gioia V, Peluso I, Caprioli F, Stolfi C, Perfetti A Spagnoli LG, Palmieri G, Macdonald TT, Monteleone G: Protease-activated receptor-2 activation in gastric cancer cells promotes epidermal growth factor receptor trans-activation and proliferation. Am J Pathol 2006, 169:268-278.

26. Wang Y, Luo W, Reiser G: Activation of protease-activated receptors in astrocytes evokes a novel neuroprotective pathway through release of chemokines of the growth-regulated oncogene/cytokine-induced neutrophil chemoattractant family. Eur J Neurosci 2007, 26:3159-3168.

27. Shpacovitch VM, Seeliger S, Huber-Lang M, Balkow S, Feld M, Hollenberg MD, Sarma VJ, Ward PA, Strey A, Gerke V, Sommerhoff CP, Vergnolle N, Steinhoff M: Agonists of proteinase-activated receptor-2 affect transendothelial migration and apoptosis of human neutrophils. Exp Dermatol 2007, 16:799-806.

28. Ding SZ, Smith MF Jr, Goldberg JB: Helicobacter pylori and mitogenactivated protein kinases regulate the cell cycle, proliferation and apoptosis in gastric epithelial cells. J Gastroenterol Hepatol 2008, 23(7 Pt 2):e67-78.

29. Choi IJ, Kim JS, Kim JM, Jung HC, Song IS: Effect of inhibition of extracellular signal-regulated kinase 1 and 2 pathway on apoptosis and bcl-2 expression in Helicobacter pylori-infected AGS cells. Infect Immun 2003, 71:830-837.

30. Suzuki T, Moraes TJ, Vachon E, Ginzberg HH, Huang TT, Matthay MA, Hollenberg MD, Marshall J, McCulloch CA, Abreu MT, Chow CW Downey GP: Proteinase-activated receptor-1 mediates elastase-induced apoptosis of human lung epithelial cells. Am J Respir Cell Mol Biol 2005, 33:231-247.

31. Chalmers CJ, Balmanno K, Hadfield K, Ley R, Cook SJ: Thrombin inhibits Bim ( $\mathrm{BCl}$-2-interacting mediator of cell death) expression and prevents serum-withdrawal-induced apoptosis via protease-activated receptor 1 . Biochem J 2003, 375(Pt 1):99-109.

32. Borensztajn KS, Bijlsma MF, Groot AP, Brüggemann LW, Versteeg HH, Reitsma PH, Peppelenbosch MP, Spek CA: Coagulation factor Xa drives tumor cells into apoptosis through $\mathrm{BH} 3$-only protein Bim up-regulation. Exp Cell Res 2007, 313:2622-2633.

33. Wang Y, Luo W, Stricker R, Reiser G: Protease-activated receptor-1 protects rat astrocytes from apoptotic cell death via JNK-mediated release of the chemokine GRO/CINC-1. J Neurochem 2006, 98:1046-1060.

34. Garcia-Cao I, Lafuente MJ, Criado LM, Diaz-Meco MT, Serrano M, Moscat J: Genetic inactivation of PAR4 results in hyperactivation of NF- $\kappa$ B and impairment of JNK and p38. EMBO Rep 2003, 4:307-312.

35. Maeda S, Yoshida H, Mitsuno Y, Hirata Y, Ogura K, Shiratori Y, Omata M: Analysis of apoptotic and antiapoptotic signalling pathways induced by Helicobacter pylori. Mol Pathol 2002, 55(5):286-293.

36. Oyake J, Otaka M, Matsuhashi T, Jin M, Odashima M, Komatsu K, Wada I, Horikawa Y, Ohba R, Hatakeyama N, Itoh H, Watanabe S: Over-expression of $70-\mathrm{kDa}$ heat shock protein confers protection against monochloramine-induced gastric mucosal cell injury. Sci 2006, 79(3):300-305.

37. Sato D, Yanaka A, Shibahara $T$, Matsui $H$, Nakahara A, Yanagawa T, Warabi $E$, Ishii T, Hyodo I: Peroxiredoxin I protects gastric mucosa from oxidative injury induced by H. pylori infection. J Gastroenterol Hepatol 2008, 23(4):652-659.

38. Slomiany BL, Slomiany A: Role of constitutive nitric oxide synthase $\mathrm{S}$ nitrosylation in Helicobacter pylori-induced gastric mucosal cell apoptosis: effect of ghrelin. Inflammopharmacology 2010.

39. Labigne A, de Reuse H: Determinants of Helicobacter pylori pathogenicity. Infect Agents Dis 1996, 5:191-202.

40. Mobley HL: Defining Helicobacter pylori as a pathogen: strain heterogenicity and virulence. Am J Med 1997, 100:2S-11S.

41. Miehlke S, Kibler K, Kim JG, Figura N, Small SM, Graham DY, Go MF: Allelic variation in the cagA gene of Helicobacter pylori obtained from Korea compared to the United States. Am J Gastroenterol 1996, 91:1322-1325. doi:10.1186/1479-5876-8-85

Cite this article as: Lim and Kim: Role of protease-activated receptor-2 on cell death and DNA fragmentation in Helicobacter pylori-infected gastric epithelial cells. Journal of Translational Medicine 2010 8:85.

\section{Submit your next manuscript to BioMed Central and take full advantage of:}

- Convenient online submission

- Thorough peer review

- No space constraints or color figure charges

- Immediate publication on acceptance

- Inclusion in PubMed, CAS, Scopus and Google Scholar

- Research which is freely available for redistribution

Submit your manuscript at www.biomedcentral.com/submit 